\title{
Characterizing local Garden Croton ('pokok puding') leaf powder as low cost biomaterial for Chromium(VI) uptake
}

\author{
Sannasi Palsan ${ }^{1, a}$, Wan Nurul Aisyah Wan Jusoh ${ }^{2}$ and Hemagowsalya Subramaniam² \\ ${ }^{1}$ Faculty of Agro Based Industry, Universiti Malaysia Kelantan, Jeli Campus, Locked Bag No. 100, 17600 Jeli, Kelantan, Malaysia \\ ${ }^{2}$ Fostem, Inti University, Putra Nilai, 71800 Nilai, N. Sembilan, Malaysia
}

\begin{abstract}
This paper reports the first ever characterization of the use of raw Garden Croton (locally known as 'pokok puding') leaf powder as low cost biomaterial for $\mathrm{Cr}(\mathrm{VI})$ removal. Biosorption experiments were carried out at ambient temperature to study the effects of initial $\mathrm{pH}(1-7)$, contact time $(15,30,45,60 \mathrm{~min})$, leaf powder's particle size $(\leq 150,151-300,301-500 \mu \mathrm{m})$, and initial $\mathrm{Cr}(\mathrm{VI})$ concentrations $(10,20,40,60,80$ and $100 \mathrm{mg} / \mathrm{L})$ towards $\mathrm{Cr}$ (VI) uptake. Optimum $\mathrm{Cr}(\mathrm{VI})$ uptake was observed at pH $1(2.41 \mathrm{mg} / \mathrm{g})$ and $2(2.19 \mathrm{mg} / \mathrm{g})(p>0.05)$. The leaf powder in the $151-300 \mu \mathrm{m}$ size displayed better $\mathrm{Cr}(\mathrm{VI})$ uptake up to $2.77 \mathrm{mg} / \mathrm{g}\left(77.78 \% ; C_{o}=100 \mathrm{mg} / \mathrm{L}\right)$ at $\mathrm{pH} 2$, after $30 \min (p<0.05)$. Equilibrium metal uptake fitted best $\left(\mathrm{R}^{2}=0.927\right)$ to the Freundlich isotherm model $\left(K_{f}=0.21\right.$ $\mathrm{mg} / \mathrm{g}, n=1.23$ ) indicating biosorption onto a heterogeneous surface of active sites. Morphological and elemental analyses by SEM/EDX and FTIR confirmed $\mathrm{Cr}$ retention, and presence of active chemical moieties. Interestingly, $\mathrm{XRD}$ revealed that $\mathrm{Cr}$ was immobilized within the biomass leaf powder in both forms, i.e. hexavalent, $\mathrm{Cr}(\mathrm{VI})$ as chromatite $\left(\mathrm{CaCrO}_{4}\right)$ and trivalent $\mathrm{Cr}(\mathrm{III})$, as chromium(III) oxide $\left(\mathrm{Cr}_{2} \mathrm{O}_{3}\right)$. Overall findings support the feasibility of the leaf powder as potential biomaterial for water pollution abatement.
\end{abstract}

\section{Introduction}

The contamination of water bodies from heavy metal ions have become a major concern because of their tendency to persist and accumulate in the ecosystem and exerting toxicity to human and nature. Among the heavy metal ions, hexavalent chromium or $\mathrm{Cr}(\mathrm{VI})$, which predominantly occurs as anionic hydrogen chromate $\left(\mathrm{HCrO}_{4}^{-}\right)$, chromate $\left(\mathrm{CrO}_{4}{ }^{2-}\right)$, and dichromate $\left(\mathrm{Cr}_{2} \mathrm{O}_{7}{ }^{2-}\right)$ in natural waters have been in greater focus as it is classified as one of the top sixteen toxic pollutants $[1,2]$. It is an oxidizing agent, highly soluble and known to be carcinogenic, mutagenic and teratogenic to living organisms [3]. By regulation, the concentration of $\mathrm{Cr}(\mathrm{VI})$ in industrial effluents should not exceed $0.1 \mathrm{mg} / \mathrm{L}$ for releases into inland waters and $0.05 \mathrm{mg} / \mathrm{L}$ for potable waters [4]. Discharge of toxic chromate and dichromate ions originates from industries involved with textile manufacturing, chrome electroplating, tanning, petrochemicals manufacturing, wood preservation, and various metal-based activities [5]. The treatment of heavy metal-laden waste can generally be divided into physicochemical and biological approach. The former includes chemical precipitation, adsorption, ion exchange, electrolysis, reverse osmosis, membrane technology, and such $[2,6]$. The physico-chemical approach requires high investment and maintenance with limited operating conditions especially at very low metal concentrations [7] and generates toxic chemical sludge which necessitate further remedial actions. Biosorption is an environmental-friendly, alternate technology for treating heavy metal polluted water and industrial wastewater. Many researchers have described the use of active and inactive biomass of microbial origins i.e. bacteria, fungi, and yeast $[8,9]$. The use of active microbial cells as was the norm before have proven to be more tedious and cost demanding in the long run. Living cells need to be supplied with nutrient to ensure sustained growth. Even the use of non-living microbial cells necessitates the cultivation of the cells prior to their use. Nowadays, the trend has shifted to use low cost biowaste or biomass materials as biosorbents for heavy metal biosorption and sequestration. Some of the work involving agricultural or plant waste include papaya wood, maize, peanut hull, grape stalk, sago, neem, rice husks, rice bran, wheat bran, paddy straw, palm oil fibre, sawdust, alfa grass, and moss peat $[1,2,7,10,11]$. However, not many studies have explored using garden refuse as potential biosorbents material. This is encouraging because naturally occurring garden refuse can be utilized effectively and economically. Low cost treatment options will be better received for implementation by the industry operators. Finding a useful purpose for the garden refuse can eliminate the burning of leaves and other yard refuse which contributes to environmental pollution and deteriorating aesthetic value of the location.

Garden Croton (Codiaeum variegatum; Croton, $\mathrm{CV}$ ) or locally known as 'pokok puding' belongs to the

\footnotetext{
a Corresponding author: palsan.abdullah@umk.edu.my
} 
Euphorbiaceae family. It is characterised by the 'batik' patterned mixture of red, yellow, and green leaf colour. In this study, unmodified withered fallen dead leaves were used. So far, literature has yet to capture the use of 'puding' or Garden Croton leaves as potential biosorbent material highlighting the study novelty. Leafs of different plants are highly versatile in terms of their natural organic and inorganic compounds. Several interdependent parameters governing $\mathrm{Cr}(\mathrm{VI})$ uptake and removal, i.e. $\mathrm{pH}$, particle size of biosorbent, and contact time for equilibrium were studied. This work is aimed to explore the potential of the local variety of Garden Croton ('pokok puding') plant's leaf powder to uptake $\mathrm{Cr}(\mathrm{VI})$ from aqueous solutions.

\section{Methods}

\subsection{Chemicals and reagents}

Reagents were of analytical grade and prepared using distilled water. The standard, working, and test solutions of varying $\mathrm{Cr}(\mathrm{VI})$ concentrations were made by diluting potassium dichromate $\left(\mathrm{K}_{2} \mathrm{Cr}_{2} \mathrm{O}_{7}\right)$ stock solution (1000 $\mathrm{mg} / \mathrm{L})$. The initial solution $\mathrm{pH}$ was adjusted by addition of either $1.0 \mathrm{M}$ sulfuric acid $\left(\mathrm{H}_{2} \mathrm{SO}_{4}\right)$ or $1.0 \mathrm{M}$ sodium hydroxide $(\mathrm{NaOH})$ as required.

\subsection{Leaf sourcing and biomaterial preparation}

The withered fallen dead leafs of Garden Croton ('pokok puding') plant were sourced from the shrubs growing at the university's garden, backyard, and from the local kindergarten compound. Leafs were torn into smaller pieces (the petiole and stalks were detached), washed repetitively with distilled water to remove dirt, and other adherents. Then left to air-dry overnight before placed in the convection oven for further drying for two days at $60^{\circ}$ C. The dried leaf pieces were ground with a high speed grinder (26 $000 \mathrm{rpm}, 2-3 \mathrm{~min}$ ) (Shanghai Jingke Scientific Instrument Co., Ltd., China) to powder form. The leaf powder was sieved through a series of sieves with mesh numbers of 35,48 , and 100 , corresponding to particle size ranges of 301-500, 151-300, and $\leq 150 \mu \mathrm{m}$, respectively. The sieved leaf powder was kept in air-tight containers.

\section{3 $\mathrm{pH}, \quad \mathrm{pH}_{\mathrm{pzc}}$, and moisture content determination}

About $0.5 \mathrm{~g}$ of the Croton leaf powder was mixed with $100 \mathrm{~mL}$ distilled water in a covered beaker, agitated for 10 minutes and left to stand for $1 \mathrm{~h}$. After the hour, the clear aqueous solution was separated and the $\mathrm{pH}$ measured.

A simplified mass potentiometric titration method was used to determine the point of zero charge $\mathrm{pH}\left(\mathrm{pH}_{\mathrm{pzc}}\right)$, the $\mathrm{pH}$ where the net total charge will be zero. Two identical $0.1 \mathrm{M} \mathrm{NaOH}(100 \mathrm{~mL})$ solutions were first prepared. One will be the blank solution, and the other to contain the leaf powder (test solution). For the blank solution, $0.5 \mathrm{~mL}$ of $1 \mathrm{M} \mathrm{NaOH}$ was added and $\mathrm{pH}$ was recorded. For the test solution, $0.05 \mathrm{~g}$ of leaf powder was added, followed by $0.5 \mathrm{~mL}$ of $1 \mathrm{M} \mathrm{NaOH}$, and the initial $\mathrm{pH}$ was noted. Both solutions were then titrated with $1 \mathrm{M} \mathrm{HCl}(0.2 \mathrm{~mL}$ additions each time) and the $\mathrm{pH}$ were recorded. A graph of $\mathrm{pH}$ against volume of $1 \mathrm{M} \mathrm{HCl}$ was plotted. The $\mathrm{pH}_{\mathrm{pzc}}$ of the Croton leaf powder was estimated to be at the point where both titration curves crossed, modified from [12].

For moisture content, the initial weight of $0.5 \mathrm{~g}$ of Croton leaf powder was recorded as wet weight $(\mathrm{A}, \mathrm{g})$ of sample. The leaf powder was dried in a micro oven (at 200 watts) for two minutes until the sample attained constant weight and left to cool. Then it was re-weighed and the weight recorded as dry weight $(\mathrm{B}, \mathrm{g})$ of sample. The moisture content $(\% \mathrm{M})$ of the leaf powder was calculated as: $(\mathrm{A}-\mathrm{B}) / \mathrm{B} \times 100 \%$.

\subsection{Chromium(VI) assay}

The standard assay using the $\mathrm{Cr}(\mathrm{VI})$-specific reagent 1,5diphenylcarbazide (DPC) was followed, as modified from [6]. At equilibrium time, the content of each flask was filtered through Whatman No.1 (125 mm) filter paper. The residual $\mathrm{Cr}(\mathrm{VI})$ in the filtrate was measured spectrophotometrically at $540 \mathrm{~nm}$ (Biochrom Libra S12, USA) and compared to a standard curve $\left(\mathrm{R}^{2}=0.999\right)$. The \% $\mathrm{Cr}(\mathrm{VI})$ removal is given as $=C_{o}-C_{e} / C_{o} \times 100$, and $\mathrm{Cr}(\mathrm{VI})$ uptake $\left(\mathrm{q}_{\mathrm{e}}, \mathrm{mg} / \mathrm{g}\right)=C_{o}-C_{e} / w \times$ volume of solution $(\mathrm{L})$; where $C_{o}(\mathrm{mg} / \mathrm{L})$ is the initial concentration of $\mathrm{Cr}(\mathrm{VI}), C_{e}(\mathrm{mg} / \mathrm{L})$ is the residual concentration of $\mathrm{Cr}(\mathrm{VI})$ at equilibrium, and $w$ is the dry weight of the leaf powder $(\mathrm{g})[6,13]$.

\subsection{Experimental design}

The experimental design is presented in Table 1.

Table 1. Experimental design and test parameters.

\begin{tabular}{lcccc}
\hline $\begin{array}{l}\text { Test } \\
\text { parameters }\end{array}$ & $\begin{array}{c}\text { Initial } \\
\mathrm{pH}\end{array}$ & $\begin{array}{c}\text { Particle size } \\
\text { range }(\mu \mathrm{m})\end{array}$ & $\begin{array}{c}\text { Contact } \\
\text { time }(\mathrm{min})\end{array}$ & $\begin{array}{c}\text { Initial } \\
{[\mathrm{Cr}(\mathrm{VI})]} \\
(\mathrm{mg} / \mathrm{L})\end{array}$ \\
\hline $\begin{array}{l}\text { Effect of } \\
\text { pH and } \\
\text { contact time }\end{array}$ & $1-7$ & $151-300$ & $15-60$ & 10 \\
$\begin{array}{l}\text { Effect of } \\
\text { particle size }\end{array}$ & 2 & $\leq 150-500$ & 30 & 10 \\
$\begin{array}{l}\text { Effect of } \\
\text { initial }\end{array}$ & 2 & $151-300$ & 30 & $10-100$ \\
{$[\mathrm{Cr}(\mathrm{VI})]$} & & & & \\
\hline
\end{tabular}

The test parameters were evaluated in batch mode. Biosorbent amount was fixed at $0.1 \mathrm{~g}$ and final volume of flask was $25 \mathrm{~mL}$. The flask content was agitated at 200 rpm (orbital shaker; Smith, China) in ambient temperature $\left(26 \pm 2^{\circ} \mathrm{C}\right)$. Appropriate controls (without the leaf powder) were assigned to each run.

\subsection{Batch biosorption isotherm study}

The effect of initial concentrations of $\mathrm{Cr}(\mathrm{VI})$ and isotherm studies were conducted at $C_{o}=10,20,40,60$, 80 and $100 \mathrm{mg} / \mathrm{L} ; \mathrm{pH} \mathrm{2,} \mathrm{with} 0.1 \mathrm{~g}$ leaf powder (151-300 
$\mu \mathrm{m})$ for $30 \mathrm{~min}$ and agitated at $200 \mathrm{rpm}$ in ambient temperature. Experimental data were fitted to the Langmuir and Freundlich isotherm models. The linearized Langmuir model, Eq. (1) assumes a monolayer adsorption onto a surface with a fixed number of identical sites which are equivalently distributed over the biosorbent surface without interaction between the adsorbed ions [5]. The isotherm parameters ( $b$ and $Q_{\max }$ ) can be determined from the intercept and slope of the linearized Langmuir plot.

Linearized form of Langmuir equation:

$$
\frac{C_{e}}{q_{e}}=\frac{1}{Q_{\max }} C_{e}+\frac{1}{Q_{\max } b}
$$

Where $q_{e}(\mathrm{mg} / \mathrm{g})$ is the amount of $\mathrm{Cr}(\mathrm{VI})$ uptake, $Q_{\max }$ $(\mathrm{mg} / \mathrm{g})$ is Langmuir monolayer adsorption capacity, $b$ $(\mathrm{L} / \mathrm{mg})$ is Langmuir constant-affinity of binding sites for metal ions and $C_{e}(\mathrm{mg} / \mathrm{L})$ is the residual concentration of $\mathrm{Cr}(\mathrm{VI})$ at equilibrium.

Freundlich isotherm assumes that the uptake of metal ions occurs on a heterogeneous biosorbent surface with interactions between the adsorbed ions [13]. The experimental data were tested with the linearized form of Freundlich isotherm, Eq. (2). The isotherm parameters $\left(K_{f}\right.$ and $n$ ) can be ascertained from the intercept and slope of the linearized Freundlich plot.

Linearized form of Freundlich equation:

$$
\ln q_{e}=\ln K_{f}+1 / n \ln C_{e}
$$

where $q_{e}(\mathrm{mg} / \mathrm{g})$ is the amount of $\mathrm{Cr}(\mathrm{VI})$ uptake, $K_{f}$ $(\mathrm{mg} / \mathrm{g})$ is a constant related to $\mathrm{Cr}(\mathrm{VI})$ uptake at lower equilibrium concentration of $C_{e}=1 \mathrm{mg} / \mathrm{L}\left(\log C_{e}=0\right)$, and $n$ is a constant for adsorption intensity [8].

\subsection{Characterization of leaf powder}

The morphological features of the raw leaf powder (151$300 \mu \mathrm{m})$ and the leaf powder after $30 \mathrm{~min}$ exposure to 10 $\mathrm{mg} / \mathrm{L} \mathrm{Cr}(\mathrm{VI})$ were examined with a high resolution field emission scanning electron microscope (SEM; Hitachi S$3400 \mathrm{~N}$, Japan), and the Cr(VI)-exposed leaf powder was subjected to energy-dispersive X-Ray (EDX; Thermo Scientific, USA). Functional group scan was performed with attenuated total reflectance-Fourier transform infrared (ATR-FTIR; Spectrum 100, Perkin Elmer, USA) in the range of $650-4000 \mathrm{~cm}^{-1}$.

\section{8 $\mathrm{Cr}(\mathrm{VI})$ retention study}

This study was to test $\mathrm{Cr}(\mathrm{VI})$ retention capability of the leaf powder. This capability is important when dealing with biosorbent systems in aqueous solutions. The test sample, i.e. exposed to $\mathrm{Cr}(\mathrm{VI})$ was stored in a plastic specimen bottle for more than a year at room temperature (uncontrolled). The sample was then subjected to SEM/EDX (Hitachi TM3030Plus, Japan), X-ray diffraction (XRD; Bruker D2 Phaser, Germany with
DIFFRAC.SUITE software) and x-ray fluorescence (XRF; Bruker S2 Ranger, Germany) examinations to verify and to determine the form in which $\mathrm{Cr}$ was immobilized by the leaf powder. Samples were prepared in pellet form as described in the instrument's operations manual.

\subsection{Statistical analysis}

All tests described above were carried out in triplicates and the mean is reported. The experimental data were subjected to t-tests, one-way ANOVA, and post hoc tests (IBM SPSS version 21). Significance level was set at $95 \%(\alpha=0.05)$.

\section{Results and discussion}

\section{1 $\mathrm{pH}$, moisture content and $\mathrm{pH}_{\mathrm{pzc}}$}

The $\mathrm{pH}$ of the leaf powder was $6.93 \pm 0.03$. The moisture content was $9.14 \pm 0.49 \%$. According to Pradhan et al., [14], the leaf of a plant from the genus Saraca asoca has a pH of 5 to 7 and a moisture content of around $5 \%$. The higher moisture content due to the presence of water can affect adsorption process and decrease the adsorption capacity. Figure 1 indicates $\mathrm{pH}_{\mathrm{pzc}}$ as $5.11 \pm 0.17$. This notation can be useful in explaining the mechanism of biosorption in aqueous solutions. Biosorption of cations is more preferred when the solution $\mathrm{pH}>\mathrm{pH}_{\mathrm{pzc}}$ while biosorption of anions are better when solution $\mathrm{pH}<$ $\mathrm{pH}_{\mathrm{pzc}}$. Chromate is an oxyanion which means it is negatively charged, hence for the adsorption of this oxyanion, the $\mathrm{pH}$ of the solution should be lower than 5.11. When $\mathrm{pH}<\mathrm{pH}_{\mathrm{pzc}}$ protonation of specific functional groups will occur and the biosorbent will resemble a positively charged affinity resin which attracts negatively charged ions in the solution [12].

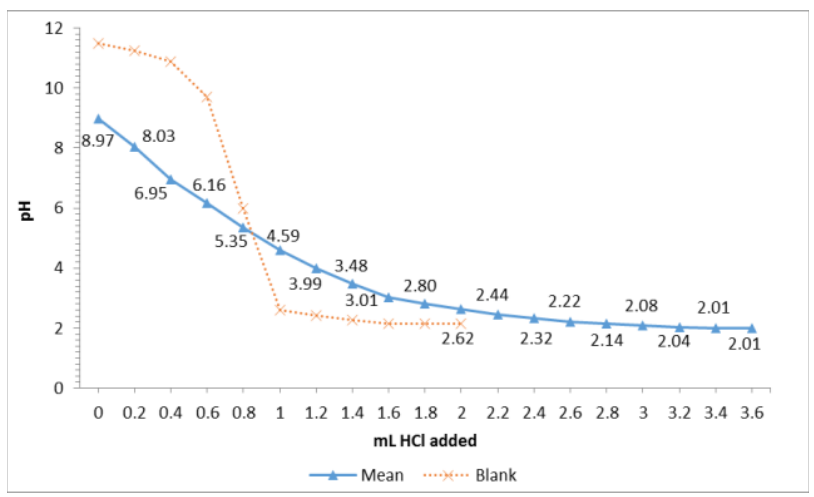

Figure 1. Titration result of Croton leaf powder for the determination of $\mathrm{pH}_{\mathrm{pzc}}$

\subsection{Effect of $\mathrm{pH}$, contact time and particle size}

The effect of initial $\mathrm{pH}$ and time towards $\mathrm{Cr}(\mathrm{VI})$ uptake by the leaf powder can be seen in Figure 2. Three distinct groups were noticeable based on $\mathrm{Cr}(\mathrm{VI})$ uptake ability ( $p$ $<0.05)$, i.e. $\mathrm{pH} 1$ and 2; $\mathrm{pH} 3$; and $\mathrm{pH} 4-7$. 


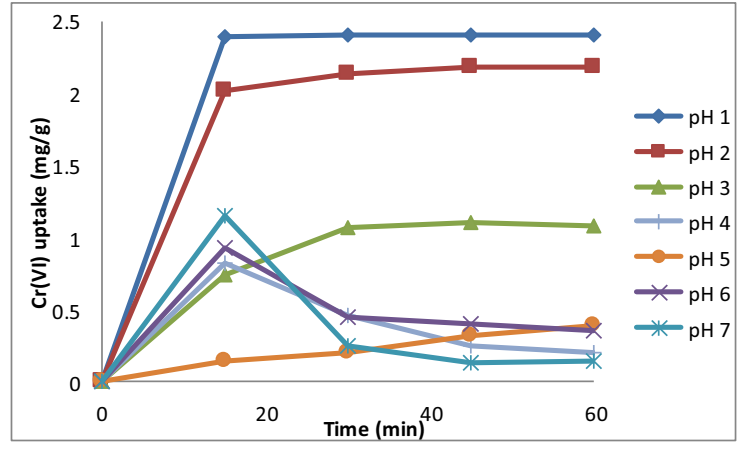

Figure 2. The effect of initial $\mathrm{pH}$ and time towards $\mathrm{Cr}(\mathrm{VI})$ uptake $(\mathrm{mg} / \mathrm{g})$ at $C_{o}=10 \mathrm{mg} / \mathrm{L}$.

The highest $\mathrm{Cr}(\mathrm{VI})$ uptake of $2.41 \mathrm{mg} / \mathrm{g}$ was read at $\mathrm{pH} 1$ after $30 \mathrm{~min}$, then at $\mathrm{pH} 2(2.19 \mathrm{mg} / \mathrm{g})$ after $45 \mathrm{~min}$. However the difference in $\mathrm{Cr}(\mathrm{VI})$ uptake between $\mathrm{pH} 1$ and $\mathrm{pH} 2$ was insignificant $(p>0.05)$. In very acidic solutions, the $\mathrm{HCrO}_{4}{ }^{2-}$ ions with a smaller ionic size will be higher in concentration thus can easily diffuse and adsorb onto the biosorbent surface [11]. The excess $\mathrm{H}^{+}$ ions cause the protonation of the chemical groups on the sorbent surface. At $\mathrm{pH}$ 2, $\mathrm{Cr}(\mathrm{VI})$ exist oxyanions; predominated by $\mathrm{HCrO}_{4}^{-}$, and followed by $\mathrm{CrO}_{4}^{2-}$, and $\mathrm{Cr}_{2} \mathrm{O}_{7}{ }^{2-}$. The preference for lower $\mathrm{pH}$ for $\mathrm{Cr}(\mathrm{VI})$ uptake is advantageous for application as electroplating baths, $\mathrm{Cr}$ containing solutions, and waste streams are generally acidic $(\mathrm{pH}<3)$ in nature [13]. The solution's $\mathrm{pH}$ is one of the most significant aspect that affects the capacity of biosorbents in aqueous solution. The weakening electrostatic force between the metal ions and the surface of the leaf powder as $\mathrm{pH}$ increases results in decrement in metal uptake. In terms of reaction time, saturation was rapid within 15 min for all tested pHs; but slightly higher uptake was apparent after $30 \mathrm{~min}$ but there was no significant $\mathrm{Cr}(\mathrm{VI})$ uptake difference between 30 and 45 $\min$ at $\mathrm{pH} 1-3(p>0.05)$. The extent of adsorption was rapid earlier on as all the active sites are vacant with high amount of available adsorbates. As time passes, the sites become fully occupied and as the biosorbent quantity is constant, no further adsorption can occur and equilibrium is achieved. On the other hand, $\mathrm{Cr}(\mathrm{VI})$ uptake decreased drastically at higher $\mathrm{pHs}$ with time. At $\mathrm{pH}$ above 3, the uptake is higher in the first 15 minutes before dropping and leveling off thereafter. This could be due to the instability and dissociation of the $\mathrm{Cr}$ complexes due to chemical speciation at higher $\mathrm{pH}$ as well as changes with the functional groups (i.e. carboxylate, phosphate and amine) present on the biomass. This may be explained due to the higher deprotonating effect of the leaf powder surface over time hence repelling the negatively charged chromates. Initial $\mathrm{pH}$ of solution is anticipated as an important factor governing the removal of $\mathrm{Cr}(\mathrm{VI})$. It influences $\mathrm{Cr}(\mathrm{VI})$ and heavy metals ionic speciation, surface charge of the leaf powder due to dissociation of active functional sites, and possible reduction of $\mathrm{Cr}(\mathrm{VI})$ to $\mathrm{Cr}(\mathrm{III})$ [2]. As $\mathrm{pH}$ increase, the competitive environment created by the presence of $\mathrm{OH}^{-}$and $\mathrm{CrO}_{4}{ }^{2-}$ leads to reduction in overall biosorption capacity [1]. There have been reports of simultaneous occurrence of adsorption and reduction [2]. The Cr chemistry may have also played a role, as the initially adsorbed $\mathrm{Cr}(\mathrm{VI})$ can be reduced to $\mathrm{Cr}(\mathrm{III})$ by interaction with the leaf powder surface. The predominant anionic $\mathrm{Cr}_{2} \mathrm{O}_{7}{ }^{2-}$ and $\mathrm{HCrO}_{4}{ }^{-}$ have the tendency to oxidize the leaf powder surface upon contact and hence become reduced [7]. The reduced $\mathrm{Cr}(\mathrm{III})$ will then be released and precipitated into the solution at higher $\mathrm{pHs}$. X-ray analyses by XRD and XRF gave a better insight on this aspect (section 3.4). Based on this outcome, subsequent studies were carried out at $\mathrm{pH} 2$ for $30 \mathrm{~min}$. Similarly, Vinodhini and Das [13] have observed optimal removal of $\mathrm{Cr}(\mathrm{VI})$ at $\mathrm{pH} 2$ with neem sawdust, mango sawdust, orange peel, wheat husk, and sugarcane bagasse. Recently, Gupta and Mote [7] had reported that the optimal $\mathrm{pH}$ for $\mathrm{Cr}(\mathrm{VI})$ uptake by sugarcane bagasse was $\mathrm{pH} 1$, saw dust at $\mathrm{pH} 1-2$, orange peels at $\mathrm{pH} \mathrm{1,} \mathrm{and} \mathrm{rice} \mathrm{husk} \mathrm{ash} \mathrm{at} \mathrm{pH}$ 1-2. However, Rezaei [3] when using Spirulina sp. observed optimal $\mathrm{Cr}(\mathrm{VI})$ uptake at $\mathrm{pH}$ 5. As mentioned above, the $\mathrm{pH}_{\mathrm{pzc}}$ of Croton leaf powder is 5.11 and this explains the better $\mathrm{Cr}(\mathrm{VI})$ uptake capacity at below this $\mathrm{pH}$. In conditions when $\mathrm{pH}>\mathrm{pH}_{\mathrm{pzc}}$, deprotonation of the functional groups on the biosorbent will turn the biosorbent to become more negatively charged hence more preferable to bind cations. The $\mathrm{pH}$ adjustment will be useful for desorption of the anions for metal ion recovery and biomass regeneration process.

As for particle size, as seen in Table 2, the highest $\mathrm{Cr}(\mathrm{VI})$ removal and uptake was $97.34 \%$ and $1.62 \mathrm{mg} / \mathrm{g}$, respectively. This was observed with the mixture containing the leaf powder in the 151-300 $\mu \mathrm{m}$ size. There was no significant difference between the 301-500 $\mu \mathrm{m}$ and 151-300 $\mu \mathrm{m}$ particle size ranges. The lowest removal was seen with the smallest powder particles, $\leq 150 \mu \mathrm{m}$ $(p<0.05)$. Although, the leaf powder with the smallest particle size is expected to have the largest surface area, it did not favour more $\mathrm{Cr}(\mathrm{VI})$ removal or uptake. The leaf powder in the particle size range of 151-300 $\mu \mathrm{m}$ was chosen for the following adsorption isotherm modelling study.

Table 2. Effect of particle size towards $\mathrm{Cr}(\mathrm{VI})$ uptake at $C_{o}=10$ $\mathrm{mg} / \mathrm{L}$ after $30 \mathrm{~min}$.

\begin{tabular}{cc}
\hline Leaf powder particle size $(\mu \mathrm{m})$ & $\mathrm{Cr}(\mathrm{VI})$ uptake $(\mathrm{mg} / \mathrm{g})$ \\
\hline $301-500$ & $1.61 \pm 0.006$ \\
$151-300$ & $1.62 \pm 0.006$ \\
$\leq 150$ & $1.56 \pm 0.027$ \\
\hline
\end{tabular}

\subsection{Effect of initial $\mathrm{Cr}(\mathrm{VI})$ concentration and adsorption isotherm studies}

This investigation was carried out at an initial $\mathrm{Cr}(\mathrm{VI})$ concentrations of $10-100 \mathrm{mg} / \mathrm{L}$ with the optimal conditions ascertained earlier, i.e. at $\mathrm{pH} 2$, with particle size of $151-300 \mu \mathrm{m}$ for $30 \mathrm{~min}$. The other conditions were as before. As observed from Figure 3, the \% removal of $\mathrm{Cr}(\mathrm{VI})$ gradually decreased from $77.78 \%$ at $10 \mathrm{mg} / \mathrm{L}$ to $62.67 \%$ at $100 \mathrm{mg} / \mathrm{L}$ as the initial $\mathrm{Cr}(\mathrm{VI})$ was increased. This is due to the limited and constant number 
of available active binding site in a batch system as opposed to the increasing concentration of $\mathrm{Cr}(\mathrm{VI})$. At equilibrium, saturation is expected to occur, with the leaf powder maximally filled with $\mathrm{Cr}$ ions per unit of surface area [11]. This results in the 10 fold increase of $\mathrm{Cr}(\mathrm{VI})$ uptake from $0.27 \mathrm{mg} / \mathrm{g}$ at $C_{o}=10 \mathrm{mg} / \mathrm{L}$ to $2.77 \mathrm{mg} / \mathrm{g}$ at $C_{o}=100 \mathrm{mg} / \mathrm{L}$.

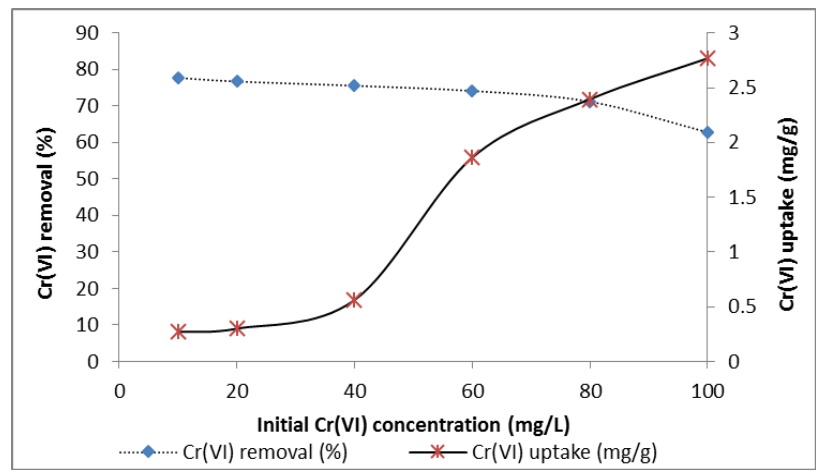

Figure 3. Effect of initial concentration of $\mathrm{Cr}(\mathrm{VI})$ towards $\mathrm{Cr}(\mathrm{VI})$ removal and uptake by 'puding' leaf powder.

The $\mathrm{Cr}(\mathrm{VI})$ uptake data fitted best to the Freundlich model $\left(K_{f}=0.21 \mathrm{mg} / \mathrm{g}, n=1.23 ; \mathrm{R}^{2}=0.927\right)$ as shown in Figure 4 as opposed to the Langmuir model which resulted in a very poor fit $\left(\mathrm{R}^{2}=-1.198\right.$; plot not shown).

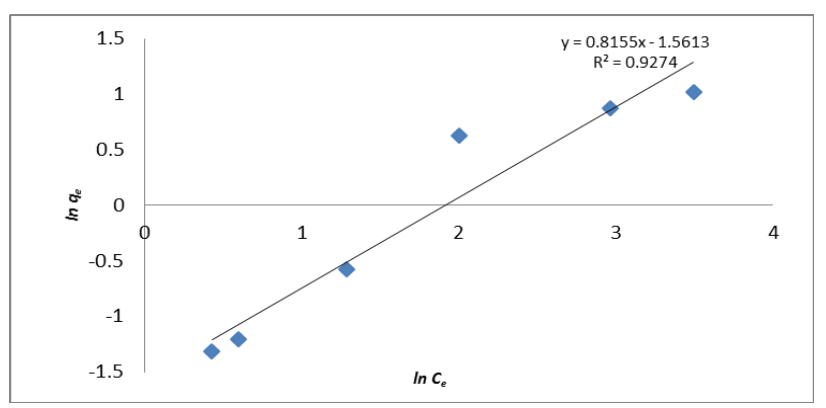

Figure 4. The Freundlich isotherm plot. Experimental conditions were as follows: biomass dose: $0.1 \mathrm{~g}$; particle size: 151-300 $\mu \mathrm{m}$; initial $\mathrm{Cr}(\mathrm{VI})$ concentration: 10, 20, 40, 60, 80, $100 \mathrm{mg} / \mathrm{L}$; $\mathrm{pH}: 2$; ambient temperature: $26 \pm 2{ }^{\circ} \mathrm{C}$; agitation speed: $200 \mathrm{rpm}$; contact time: $30 \mathrm{~min}$.

This indicated that $\mathrm{Cr}(\mathrm{VI})$ was adsorbed onto a heterogeneous surface of the leaf powder and biosorption was favourable as $1<n<10$. As the value of $n$ was below unity, chemisorption is implied for the uptake of $\mathrm{Cr}(\mathrm{VI})$. The Freundlich maximum uptake capacity, $q_{m}$ was calculated to be $8.876 \mathrm{mg} / \mathrm{g}$ at $C_{o}=100 \mathrm{mg} / \mathrm{L}$ by the following formula; $K_{f}=q_{m} / C_{\mathrm{o}}{ }^{1 / n}$ [15]. Overall, although sorption was favourable $(1<n<10)$, but uptake and removal capacity were comparatively lower with other reported biomaterials, i.e. sugarcane bagasse $\left(K_{f}=1.38\right.$ $\mathrm{mg} / \mathrm{g})$, orange peels $\left(K_{f}=1.97 \mathrm{mg} / \mathrm{g}\right)$, sawdust $\left(K_{f}=2.12\right.$ $\mathrm{mg} / \mathrm{g})$, dried rice husk $\left(K_{f}=3.22 \mathrm{mg} / \mathrm{g}\right)$, and a bacterial consortium culture $\left(K_{f}=2.86-3.85 \mathrm{mg} / \mathrm{g}\right)$, and wheat husk $\left(K_{f}=4.57 \mathrm{mg} / \mathrm{g}\right)[7,8,13]$. The higher the values of $K_{f}$ and $n$; the higher is the affinity of the biomass. To address this shortcoming, activation of the biosorbent either by physical means or chemical means or in combination, can be carried out to enhance uniformity of the biosorbent, create micro pores, and increase active surface area that can increase adsorption capacity. Chemical modification has been reported to improve adsorption capacity of adsorbents [10]. On the other hand, the low $\mathrm{Cr}(\mathrm{VI})$ uptake may also be due to the possibility that the reduced $\mathrm{Cr}(\mathrm{III})$ as suggested earlier is released and remains in the solution. In terms of mechanism governing biosorption, Rezaei [3] have outlined that it may be one or a combination of ion exchange, complexation, coordination, adsorption, electrostatic interaction, chelation and micro precipitation.

\subsection{Characterization of the Leaf Powder}

\subsubsection{SEM/EDX analysis}

The SEM micrographs of the Croton leaf powder before $\mathrm{Cr}(\mathrm{VI})$ exposure (a) and after $\mathrm{Cr}(\mathrm{VI})$ exposure (b) are shown in Figure 5. Generally, the raw leaf powder's surface was shown to be uneven, full of nooks and pockets which can support $\mathrm{Cr}(\mathrm{VI})$ adsorption and binding. Full formed pores or micro pores were not clearly visible. Nevertheless the pocket folding observed added with the natural chemical functional groups would provide the necessary binding sites.

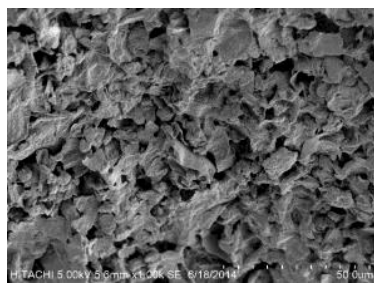

(a)

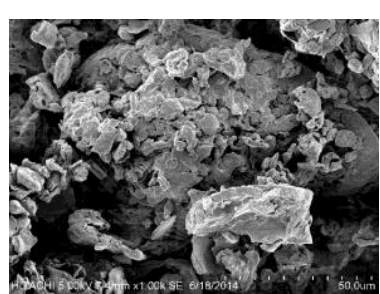

(b)
Figure 5. Scanning electron microscopy (SEM) image of the 'puding' leaf powder, (a) before $\mathrm{Cr}(\mathrm{VI})$ exposure; (b) after $\mathrm{Cr}(\mathrm{VI})$ exposure.

The leaf powder surface imaging after $\mathrm{Cr}(\mathrm{VI})$ exposure was shown to be more uneven and irregular. The high contrast area as observed in the image was assumed to be $\mathrm{Cr}$ deposits. Energy-dispersive X-ray (EDX) spectra and the quantitative tabulation are presented in Figure 6 and Table 3. The quantitative chemical analysis of the $\mathrm{Cr}(\mathrm{VI})$ exposed 'puding' leaf powder by EDX revealed the following: carbon (56.66\%), oxygen $(37.82 \% \mathrm{w} / \mathrm{w})$, calcium $(4.23 \% \mathrm{w} / \mathrm{w})$, chlorine $(0.11 \% \mathrm{w} / \mathrm{w}), \mathrm{Zn}(1.00$ $\% \mathrm{w} / \mathrm{w})$, and chromium $(0.18 \% \mathrm{w} / \mathrm{w})$. The abundance of calcium, chlorine, and zinc present on the leaf powder biomass may favour both ionic exchange and covalent bonding of the $\mathrm{Cr}$ ions. The detected $\mathrm{Ca}$ can be traced to the $\mathrm{CaO}$ compound as one of the natural constituents of leaf material. This is an apparent advantage in using natural biomaterial. The loaded $\mathrm{Cr}$ detected confirmed the capability of garden croton leaf powder as a potential biosorbent. Further extensive work are in progress in the laboratory to elaborate upon the mechanisms of biosorption within the leaf powder. 


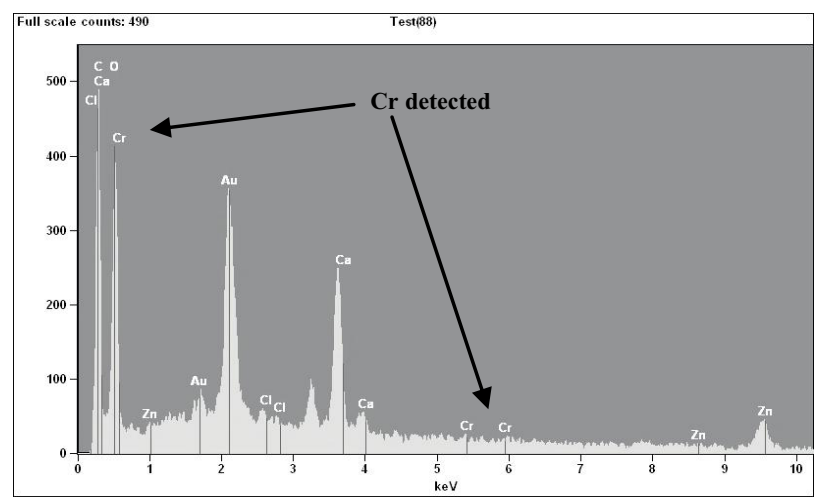

Figure 6. The SEM/EDX spectrum of test 'puding' leaf powder [after $\mathrm{Cr}(\mathrm{VI})$ exposure]. The elements map spectra was generated from samples shown in Fig. 5(b).

Table 3. Quantitative chemical analysis of test 'puding' leaf powder by EDX [after $\mathrm{Cr}(\mathrm{VI})$ exposure].

\begin{tabular}{lccccccc}
\hline Element & $\mathrm{C}$ & $\mathrm{O}$ & $\mathrm{Ca}$ & $\mathrm{Cl}$ & $\mathrm{Zn}$ & $\mathrm{Cr}$ & $\mathrm{T} \%$ \\
\hline Weight \% & 56.66 & 37.82 & 4.23 & 0.11 & 1.00 & 0.18 & 100 \\
Atom \% & 51.95 & 46.18 & 1.55 & 0.05 & 0.23 & 0.05 & 100 \\
\hline
\end{tabular}

\subsubsection{Cr(VI) retention}

The SEM/EDX imaging of (a) control and (b) test leaf powder samples stored over a year is presented in Figure 7.

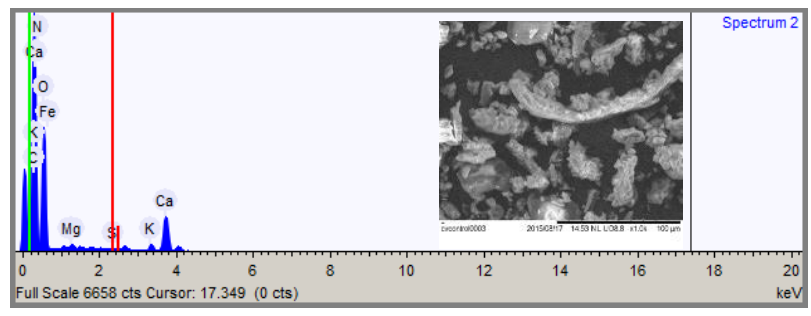

(a)

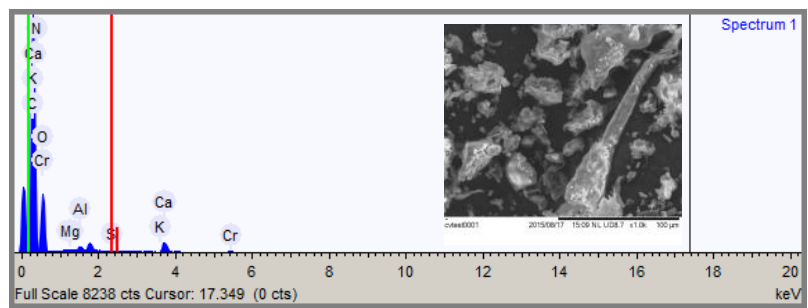

(b)

Figure 7. The SEM/EDX images and spectrum of the 'puding' leaf powder, (a) control sample (after more than 1 year); (b) test sample (after more than 1 year).

The EDX spectrum of the test sample clearly marked the loaded and retained Cr. Chemical analysis of both the control and test stored samples by EDX provided quantitative indication of element content fluctuations over the year. This also verified the retention of $\mathrm{Cr}$ $(0.41 \%)$ quantitatively in the test sample. The other major elements measured (in comparison with control and test) were as follows: $\mathrm{C}$ increased $(42 \%$ to $56.90 \%)$, O decreased $(34.14 \%$ to $45.87 \%), \mathrm{N}$ decreased $(7.47 \%$ to $6.49 \%)$, and $\mathrm{Ca}$ decreased $(3.77 \%$ to $1.56 \%)$. The ability of a biosorbent system to retain the adsorbate over time is to be given due attention. The question whether a biosorbent especially those intended to work in an aqueous solution might release its load will have to be investigated, and not many studies have actually reported on this matter. The leaching of the adsorbed toxic material into the environment is hazardous to the wellbeing of all living entity. For environmental remedial application, this is one factor that needs to be considered strongly. These findings will strengthen any suggested future use of the Croton leaf powder as potential biosorbent material. Furthermore, this revealed that over time, the adsorbed hazardous heavy metal, i.e. chromium will not be leached into the environment after the biosorption process. Thus, the safety of humankind and animals are better assured.

Through XRD observation (Figure 8), it was confirmed that $\mathrm{Cr}$ was immobilized within the biomass leaf powder. Interestingly, the adsorbed $\mathrm{Cr}$ was in both hexavalent, $\mathrm{Cr}(\mathrm{VI})$ and trivalent $\mathrm{Cr}(\mathrm{III})$ forms.

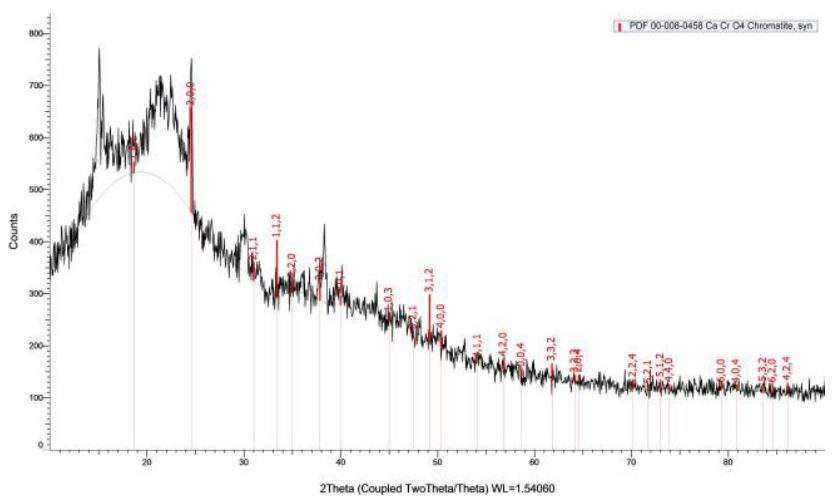

(a)

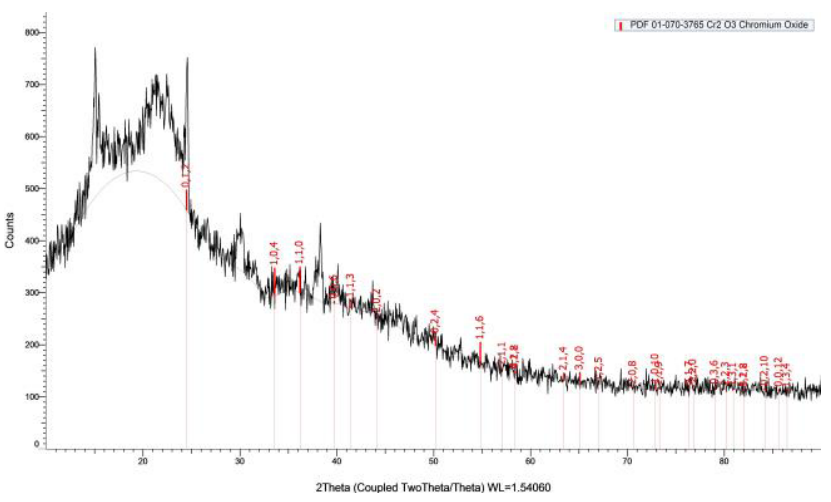

(b)

Figure 8. XRD spectrum of test 'puding' leaf powder after biosorption indicating (a) the complexation of $\mathrm{Cr}(\mathrm{VI})$ to $\mathrm{Ca}$ to form chromatite $\left(\mathrm{CaCrO}_{4}\right)$ and (b) the product of non-enzymatic reduction of $\mathrm{Cr}(\mathrm{VI})$ to $\mathrm{Cr}(\mathrm{III})$ in the form of chromium oxide $\left(\mathrm{Cr}_{2} \mathrm{O}_{3}\right)$.

The hexavalent form existed as a complex with $\mathrm{Ca}$, i.e. chromatite $\left(\mathrm{CaCrO}_{4}\right)$. Whereas the reduced trivalent form was seen as chromium(III) oxide $\left(\mathrm{Cr}_{2} \mathrm{O}_{3}\right)$. This would be made possible by the presence of oxygen (Figure 7) as determined earlier acting as the electron donor. This suggests the non-enzymatic reduction of toxic hexavalent 
chromium to the much less toxic, and less soluble $\mathrm{Cr}$ (III). As to date, to the best of our knowledge, this is the first ever report and finding of possible non-enzymatic reduction of $\mathrm{Cr}$ (VI to $\mathrm{Cr}$ (III) with garden croton leaf powder. However, comparison between the amount of $\mathrm{Cr}$ adsorbed and the amount of $\mathrm{Cr}$ reduced prior to adsorption is not reported in this work. Further to this, in order to quantitatively elucidate the chemical form in which the elements were found, quantitative analysis of the compound types present in the biomass was also performed by XRF test (plot not shown). The data outputs clearly showed that the two highest concentration of oxides in the leaf powder were $\mathrm{CaO}$ (57.5\%) and $\mathrm{Cr}_{2} \mathrm{O}_{3}(10.8 \%)$. The other oxide compounds read were: $\mathrm{SO}_{3}$ (9.83\%), $\mathrm{SiO}_{2}(6.12 \%), \mathrm{P}_{2} \mathrm{O}_{3}(4.96 \%), \mathrm{Cl}$ (3.7\%), $\mathrm{K}_{2} \mathrm{O}(2.25 \%), \mathrm{Al}_{2} \mathrm{O}_{3}(1.67 \%), \mathrm{Fe}_{2} \mathrm{O}_{3}(1.67 \%), \mathrm{BaO}$ $(0.22 \%)$. The abundance of $\mathrm{Ca}$ in the leaf powder correlated well with its ability to form complexes with $\mathrm{Cr}$ as a way to immobilize the toxic metal ion. This verified $\mathrm{Cr}(\mathrm{VI})$ uptake from aqueous solution by the garden croton leaf powder. The cation $\left(\mathrm{Ca}^{2+}\right)$ accepted the electrons from the anionic chromate $\left(\mathrm{CrO}_{4}{ }^{2-}\right)$ to form the chromatite complex. The complex was proven to be stable even after more than a year. This characteristic is important for toxic ion removal as to restrict any untoward leakage back to the environment, and this will prove to be beneficial as well for time-constrained storage before possible metal ion recovery can be opted by the industry.

\subsubsection{FTIR analysis}

The FTIR peak attributes are presented in Table 4. The FTIR scan spectra for both (a) control and (b) test leaf powders are depicted in Figure 9. In general, the 'puding' leaf powder displayed many peaks that can be assigned to major $-\mathrm{OH}$ stretch of alcohols, phenols and carboxylic acids, $\mathrm{C}=\mathrm{O}$ stretch of carboxylic acids and aldehydes, and -N-H stretch of both aliphatic and aromatic amines, and the common alkanes $(-\mathrm{CH})$, and acyl (-C-O) moieties, among others, characteristics of natural biological compound origin. Comparisons can be made between the control [not exposed to $\mathrm{Cr}(\mathrm{VI})$ ] and the test [after $\mathrm{Cr}(\mathrm{VI})$ exposure] spectra (Figure 9); the shifts observed in the wavelength of the dominant peaks i.e. peak no. 1, 2, 4, 5, 6 , and 7 denoted there was $\mathrm{Cr}$ binding process taking place at the surface of the leaf powder. Interestingly, two new peaks (peak no. 3 and 11) were detected after $\mathrm{Cr}(\mathrm{VI})$ exposure. The peaks can be assigned to $-\mathrm{C}-\mathrm{N}$ stretch of aliphatic amines or $-\mathrm{C}-\mathrm{O}$ stretch; two common groups significant for the binding of heavy metal ions and complexation. This and the shifts in the group's chemical group stretch indicate formation of new chemical bonding or association with the $\mathrm{Cr}$ ion. The vibration stretch observed with $\mathrm{OH}, \mathrm{NH}$ and $\mathrm{C}, \mathrm{O}$ groups reflect their involvement in aiding to $\mathrm{Cr}$ biosorption [3]. As the solution is acidic, the excess $\mathrm{H}^{+}$ions cause the protonation of the chemical groups on the biomass surface. At $\mathrm{pH} 2, \mathrm{Cr}(\mathrm{VI})$ exist in anionic form; predominated by $\mathrm{HCrO}_{4}{ }^{-}$, and followed by $\mathrm{CrO}_{4}{ }^{2-}$, and $\mathrm{Cr}_{2} \mathrm{O}_{7}{ }^{2-}$. The more positively charged surface and the protonated carboxyls, carbonyls, amines, and amides promote electrostatic attractions with the anionic $\mathrm{Cr}(\mathrm{VI})$ ions in the solution [5]. It has been postulated that $\mathrm{Cr}(\mathrm{VI})$ reduction to $\mathrm{Cr}(\mathrm{III})$ is possible with non-living biomass as well. Chromium(VI) carry a very high positive redox potential $(+1.33 \mathrm{~V})$ in acidic conditions thus behaves as strong oxidizing agents, and unstable in the presence of electron donors [2] which are the reactive $-\mathrm{OH},-\mathrm{NH}$, and $-\mathrm{C}-\mathrm{O}$ or $-\mathrm{C}=\mathrm{O}$ groups found on the leaf powder. These reactive groups will then reduce $\mathrm{Cr}(\mathrm{VI})$ to $\mathrm{Cr}(\mathrm{III})$ complex for a possible electrostatic adsorption coupled reduction complexation mechanism. The occurrence of non-enzymatic reduction of $\mathrm{Cr}(\mathrm{VI})$ to $\mathrm{Cr}(\mathrm{III})$ was established by the observation of reduced $\mathrm{Cr}$ (III) in the form of $\mathrm{Cr}_{2} \mathrm{O}_{3}$ within the leaf powder as reflected in the $\mathrm{XRD}$ and XRF outputs. However, the final $\mathrm{pH}$ of the test solution after $30 \mathrm{~min}$ increased up to $\mathrm{pH}$ 4-4.49 (data not shown) at $1-100 \mathrm{mg} / \mathrm{L}$ of $\mathrm{Cr}(\mathrm{VI})$. This points to probable precipitation of $\mathrm{Cr}(\mathrm{OH})_{3}$ and/or exchange of $\mathrm{OH}^{-}$ions with $\mathrm{HCrO}_{4}{ }^{-}$apart from or in addition to the reduction of $\mathrm{Cr}(\mathrm{VI})$ to the oxide form. This might explain the lower $\mathrm{Cr}(\mathrm{VI})$ uptake and loading $\left(K_{f}=0.21 \mathrm{mg} / \mathrm{g}\right)$ with this leaf powder as the adsorbed $\mathrm{Cr}(\mathrm{VI})$ ions are precipitated back into the solution after undergoing reduction. In addition, anionic exchange can also be anticipated with the presence of $\mathrm{Cl}$ on the leaf powder. The $\mathrm{C}-\mathrm{Cl}$ stretch (peak no. 13) matched the $\mathrm{Cl}$ detected in the EDX and XRD analyses (Figure 6; Table 3). A biosorbent prepared from biowaste materials can sequester metal ions through a variety of mechanisms mainly adsorption, complexation, and ion exchange, and can actually be dubbed as a biophysico-chemical technique. The findings strongly supports the suitability of the leaf powder as a low cost biosorbent material due to the abundance in the chemical groups present.

Table 4. Classification of functional groups on CV control [leaf powder not exposed to $\mathrm{Cr}(\mathrm{VI})$ ] and CV test [leaf powder exposed to $\mathrm{Cr}(\mathrm{VI})]$ determined by FTIR scanning.

\begin{tabular}{|c|c|c|c|}
\hline $\begin{array}{l}\text { Peak } \\
\text { no. }\end{array}$ & $\begin{array}{c}\mathrm{CV} \text { (control) } \\
\left(\mathrm{cm}^{-1}\right)\end{array}$ & $\begin{array}{l}\text { CV (test) } \\
\left(\mathrm{cm}^{-1}\right)\end{array}$ & $\begin{array}{l}\text { Probable functional } \\
\text { groups [2] }\end{array}$ \\
\hline 1 & 3402 & 3408 & $\begin{array}{c}-\mathrm{OH} \text { (alcohols, } \\
\text { phenols), }-\mathrm{NH},-\mathrm{NH}_{2}\end{array}$ \\
\hline 2 & $\begin{array}{l}2969,2904 \\
2834\end{array}$ & $\begin{array}{l}2962 \\
2915 \\
2844\end{array}$ & $\begin{array}{c}-\mathrm{CH},-\mathrm{OH} \text { (carboxylic } \\
\text { acids) }\end{array}$ \\
\hline $3 *$ & & 2321 & $\begin{array}{c}-\mathrm{PH}, \mathrm{R}_{2} \mathrm{HP}=\mathrm{S},-\mathrm{OH},- \\
\mathrm{NH}\end{array}$ \\
\hline 4 & 2013 & 2007 & $\mathrm{R}-\mathrm{N}=\mathrm{C}=\mathrm{S}$ \\
\hline 5 & 1768,1717 & $\begin{array}{l}1765 \\
1719\end{array}$ & $\begin{array}{l}-\mathrm{C}=\mathrm{O} \text { (aldehydes, } \\
\text { carboxylic acids) }\end{array}$ \\
\hline 6 & 1620 & 1634 & -NH (1 ${ }^{\circ}$ amines $)$ \\
\hline 7 & 1433 & 1442 & -C-C- (aromatics) \\
\hline 8 & 1376 & 1377 & $-\mathrm{CH}$ \\
\hline 9 & 1319 & 1319 & $-\mathrm{NO}, \mathrm{C}=\mathrm{O}, \mathrm{C}-\mathrm{N}$ (amide \\
\hline 10 & 1223 & 1223 & -C-N (aliphatic amines) \\
\hline $11^{*}$ & & 1164 & $\begin{array}{c}\text {-C-N (aliphatic amines), } \\
-\mathrm{CH}, \mathrm{C}-\mathrm{O}\end{array}$ \\
\hline 12 & 1036 & 1037 & $\begin{array}{c}-\mathrm{C}-\mathrm{N} \text { (aromatic } \\
\text { amines), } \mathrm{S}=\mathrm{O}\end{array}$ \\
\hline 13 & 780,682 & 781,680 & $-\mathrm{C}-\mathrm{Cl}$ \\
\hline
\end{tabular}




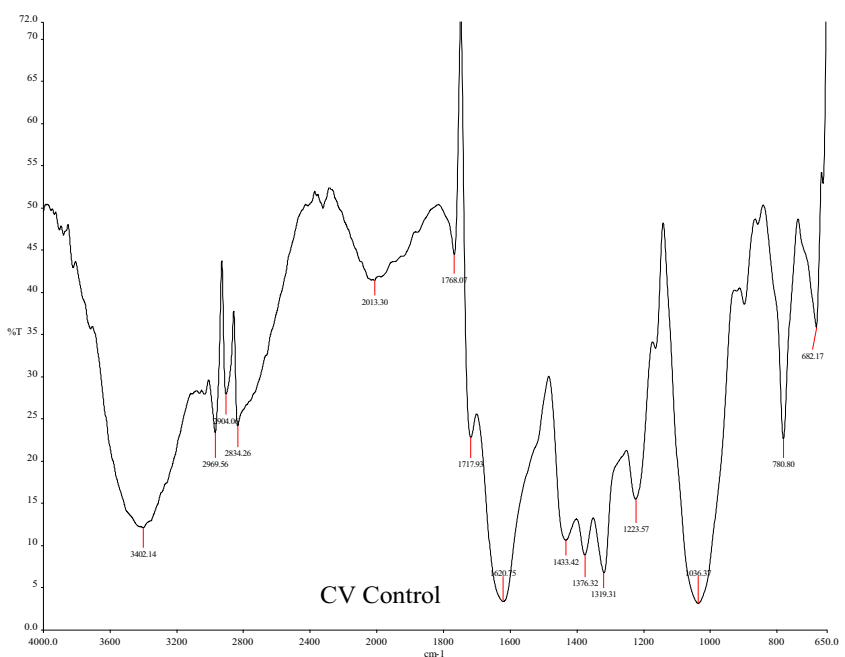

(a)

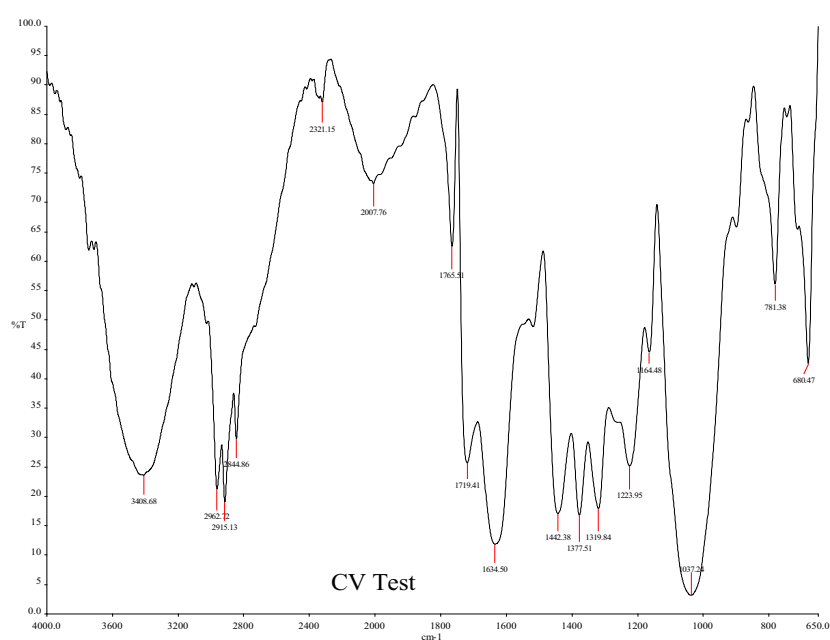

(b)

Figure 9. FTIR spectra of the 'puding' leaf powder; (a) control [not exposed to $\mathrm{Cr}(\mathrm{VI})$ ] and (b) test [after exposure to $\mathrm{Cr}(\mathrm{VI})$ ].

\section{Conclusion}

Although many studies have been carried out to study biosorption following similar schemes, it is evident that different organisms or materials do behave differently. The chemical makeup of each biosorbent material and the interacting immediate environment dictates the outcome of the overall process. Based on the findings of this study, the following can be concluded of the local garden croton leaf powder: (1) $\mathrm{Cr}(\mathrm{VI})$ uptake and removal is governed by initial solution $\mathrm{pH}$, with $\mathrm{pH} 1$ and 2 being the better options; (2) $\mathrm{The}_{\mathrm{pH}}$ is 5.11 thus anionic biosorption is best below this $\mathrm{pH}$, and cationic biosorption best above this $\mathrm{pH}$; (3) The optimal time for the biosorption process is $30 \mathrm{~min}$; (4) The leaf powder biomass in the particle size range of 150-300 $\mu \mathrm{m}$ displayed higher $\mathrm{Cr}(\mathrm{VI})$ uptake capacity; (5) Biosorption followed the Freundlich model of heterogeneous surface binding with a $K_{f}$ of $0.21 \mathrm{mg} / \mathrm{g}$ and $n=1.23$; (6) The raw leaf powder displayed many nooks and pockets but void of any visible pores; (7) The leaf powder is rich in chemical functional groups that can facilitate $\mathrm{Cr}(\mathrm{VI})$ binding and adsorption; (8) The potential of the leaf powder to adsorb both $\mathrm{Cr}(\mathrm{VI})$ and $\mathrm{Cr}$ (III) and retain the adsorbed $\mathrm{Cr}$ had been proven; (9) An electrostatic adsorption (complexation) coupled nonenzymatic reduction of $\mathrm{Cr}(\mathrm{VI})$ to $\mathrm{Cr}(\mathrm{III})$, with anionic exchange seems to be the apparent governing mechanisms for $\mathrm{Cr}(\mathrm{VI})$ removal; and (10) $\mathrm{Cr}$ was immobilized within the biomass leaf powder in both forms, i.e. hexavalent, $\mathrm{Cr}(\mathrm{VI})$ as chromatite $\left(\mathrm{CaCrO}_{4}\right)$ and trivalent $\mathrm{Cr}(\mathrm{III})$, as chromium(III) oxide $\left(\mathrm{Cr}_{2} \mathrm{O}_{3}\right)$. Although biosorption was favourable $(1<n<10)$, but uptake capacity was comparatively lower with other reported biomaterials; future studies will look into activation options to augment the $\mathrm{Cr}(\mathrm{VI})$ uptake capability of the leaf powder. This will be seconded with a column study to understand process kinetics and possible upscaling. Nevertheless, the local garden Croton ('puding') leaf litter or garden waste is proven to have bioadsorbent properties that is worthy to be developed further as low cost biomaterial for pollution abatement.

\section{Acknowledgment}

This work is supported by Universiti Malaysia Kelantan [R/SGPB/A07.00/01397A/001/2015/000305] and Inti.

\section{References}

1. M. Nameni, M. Moghadam, M. Arami, Intl. J. Environ. Sci. Tech. 5, 161 (2008)

2. B. Catalin, D. Bilba, M. Macoveanu, Cellulose Chem. Technol. 43, 99 (2009)

3. H. Rezaei, Arab. J. Chem. Retrieved from http://www.sciencedirect.com/science/article/pii/S18 7853521300378X (2013)

4. M. J. Amiri, E. Fadaei, A. Baghvand, Z. Ezadkhasty, Int. J. Environ. Res. 8, 2 (2014)

5. V. Vinodhini, V. Anabarasu, N. Das, Ind. J. Nat. Prod. Res. 1, 174 (2010)

6. P. Sannasi, C. S. Fern, S. Bernadine, L. F. Shiang, J. Trop. Res. Sustain. Sci. 3, 35 (2015)

7. A. Gupta, S. R. Mote, Chem. Process Eng. Res. 19, 47 (2014)

8. P. Sannasi, J. Kader, B.S. Ismail, S. Salmijah, Bioresour. Technol. 97, 740 (2006)

9. K. Selvam, K. Arungandhi, B. Vishnupriya, T. Shamuga, M. Yamuna, Biosci. Discov. 72 (2013)

10. W. S. Wan Ngah, M. A. K. M. Hanafiah, Bioresour. Technol. 99, 3935 (2008)

11. N. Tazrouti, M. Amrani, BioResour. 4, 740 (2009)

12. A. M. C. Pena, J. G. Ibanez, R.V. Medrano, Retrieved from http://www.electrochemsci.org/papers/vol7/707614 2.pdf (2012)

13. V. Vinodhini, N. Das, ARPN J. Agric. Biol. Sci. 4, 19 (2009)

14. P. Pradhan, L. Joseph, V. Gupta, R. Chulet, H. Arya, R. Verma, A. Bajpai, J. Chem. Pharma. Res. 1, 62 (2009)

15. O. Hamdaoui, E. Naffrechoux, J. Hazard Mat. 147, 381 (2007) 